\title{
Bulky Vehicles Recycling. Part 2 - Recycling of Selected Vehicle Components
}

\author{
Recykling pojazdów wielkogabarytowych. Część 2 - recykling wybranych komponentów pojazdu
}

\author{
Anna Matuszewska ${ }^{1}$, Piotr Wieczorek ${ }^{2}$, Marlena Owczuk ${ }^{2}$ \\ ${ }^{1}$ Faculty of Christian Philosophy, Cardinal Stefan Wyszyński University in Warsaw, Poland \\ ${ }^{2}$ Automotive Industry Institute, Łukasiewicz Research Network, Warsaw, Poland \\ ORCID: AM https://orcid.org/0000-0002-7853-7401; PW https://orcid.org/0000-0002-7605-9733; \\ M0 https://orcid.org/0000-0001-9024-2537•a.matuszewska@uksw.edu.pl \\ Received: 26 July 2020; Revised: 29 Sep 2020; Accepted: 09 Oct 2020
}

\begin{abstract}
Recycling of end-of-life passenger vehicles is a well-known topic, and there are many literary reports in this regard. However, little information is available on the recycling of bulky vehicles, which determines the authors' intention to present this issue. The article describes the recycling methods for selected components (tires, windows, catalytic converters, polymer and metal materials, operating fluids), with an indication of the differences between heavy goods vehicles and passenger cars. Examples of large corporations producing vehicles, whose activities facilitate the recycling and segregation of materials used in bulky vehicles, are presented. These corporations meet the changes taking place, and implement the principles of the circular economy, in the field of recycling large-size vehicles. It has been shown that there are still many challenges in the field of vehicle recycling, in particular, with regard to composite materials, and for some recycling technologies, there is still a lack of adequate infrastructure in Poland.
\end{abstract}

Keywords: recycling, truck, road tractor

Streszczenie: Recykling pojazdów osobowych wycofanych z eksploatacji jest tematem znanym i w tym zakresie można znaleźć wiele doniesień literaturowych. Natomiast niewiele informacji jest dostępnych na temat recyklingu pojazdów wielkogabarytowych, dlatego intencją autorów było przedstawienie tego zagadnienia. W artykule opisano metody recyklingu wybranych komponentów (opon, szyb, reaktorów katalitycznych, materiałów polimerowych i metalowych, płynów eksploatacyjnych) ze wskazaniem różnic między samochodami ciężarowymi a samochodami osobowymi. Przedstawiono przykłady dużych korporacji produkujących pojazdy, których działania ułatwiają recykling i segregację materiałów używanych w pojazdach wielkogabarytowych. Korporacje te wychodzą naprzeciw zachodzącym zmianom i wdrażają zasady gospodarki o obiegu zamkniętym w zakresie recyklingu pojazdów wielkogabarytowych. Wykazano, że wciąż istnieje wiele wyzwań w zakresie recyklingu pojazdów, w szczególności w odniesieniu do materiałów kompozytowych, a dla niektórych technologii recyklingu w Polsce wciąż brakuje odpowiedniej infrastruktury.

Słowa kluczowe: recykling, pojazd ciężarowy, ciągnik drogowy 


\section{Introduction}

Every year, a significant number of vehicles move on our roads transporting various types of cargo. These include, among others, delivery vehicles, trucks, tractor units, ballast tractors. These vehicles, just like passenger cars, are considered waste after decommissioning. Handling of end-of-life vehicles is governed by the relevant EU Directive (Directive 2000/53/EC) and the national Act on the recycling of end-of-life vehicles (Act 2005). After the 2007 amendments (Directive 2007/46/EC), these acts have not been updated and thus only apply to passenger cars and vehicles for the transport of goods, whose maximum weight does not exceed 3.5 tonnes. Unfortunately, they do not include bulky vehicles (trucks, buses). However, it is thought that in the near future this group of vehicles will also be recycled due to the new trend of the pursuit of a circular economy. Large-size vehicles are subject to the same recycling methods as passenger vehicles, i.e. product, material and energy recycling. However, due to the size and general construction other than passenger cars, the dismantling of these vehicles is somewhat and the share of individual construction materials in the mass of the vehicle is slightly different. The recycling of bulky vehicles can be carried out by specialized companies, but some manufacturers have separated departments in their companies responsible for the end-of-life recycling of their own brands cars.

In the article constituting the first part, the authors discussed the forms of recycling large-size vehicles, design changes and their impact on recycling, and presented examples of concerns producing vehicles that disassemble and reuse elements from end-of-life vehicles. This article, which is the second part, will present the recycling of selected elements of bulky vehicles.

\section{Trends in vehicle construction materials}

The purpose of vehicle recycling is primarily to recover materials used for their construction. This recovery is becoming increasingly difficult due to the increasing tendency to participate in the construction of the vehicle composite materials. The purpose of using composites is primarily to reduce the curb weight of vehicles (reducing fuel consumption and thereby reducing carbon dioxide emissions (Stopka et al. 2018, 129) by replacing elements previously made of iron and steel. Their share in the construction is slowly increasing due to the high cost of these materials, production difficulties and significant problems with their recycling. Other materials used to reduce weight are magnesium, aluminum, copper, carbon fibres and high-strength steel (Fentahun and Savaş 2018; Mayyas, Mayyas and Omar 2016).

Many manufacturers of bulky vehicles are increasingly introducing composite materials or materials made of plastic (Miller et al. 2014) to not only reduce weight, but also improve the functionality and aesthetics of vehicles. At the same time, they also ensure that new materials do not significantly affect vehicle costs. In terms of costs, steel falls out better than magnesium, aluminium or reinforced composites, but is heavier. Although the work carried out in recent years on improving steel has increased the strength of this material tenfold. As a result, thinner components could be used and, for example, Volvo Trucks incorporates manufactures cabs in their vehicles with high-strength steel while ensuring the safety of drivers (Wartgow 2020).

This trend of reducing the weight of vehicles applies to both trucks and passenger cars. Figure 1 shows how the structure of materials used in vehicle construction changed in the years. Lighter construction materials such as plastics, composite materials or light metals are increasingly being chosen by vehicle designers (Todor and Kiss 2016). Carbon fiber reinforced composites are very popular because they are very light and characterized by high yield strength. Unfortunately, their disadvantage is the price - they are among the most expensive 


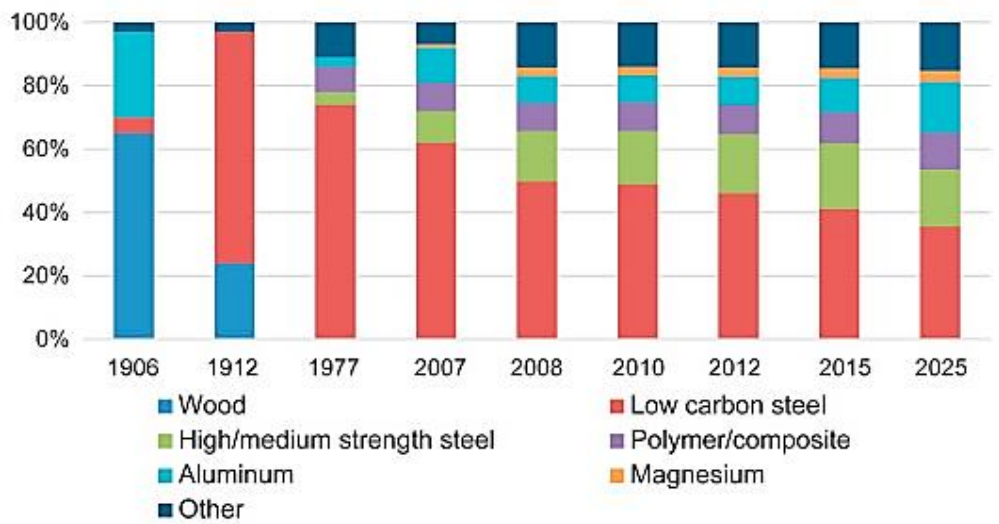

Figure 1. Average materials content in the vehicle in historical terms (Mayyas, Mayyas and Omar 2016)

materials in the automotive industry (Fentahun and Savaş 2018).

Vehicle manufacturers take into account several criteria when choosing materials (Fentahun and Savaş 2018; Wilhelm 1993; Synák et al. 2019, 41):

- cost reduction - both materials should be relatively cheap and their manufacturing processes;

- low weight - lower vehicle weight translates into lower fuel consumption and thus lower emissions to the atmosphere, which is a very important criterion in the context of modern requirements;

- the possibility of recycling elements made of these materials, the cost of recycling and environmental impacts (Life Cycle Assessment),

- mechanical properties including those affecting safety such as the ability of material to absorb impact energy.

However, it is worth paying attention to the fact that despite the use of ever lighter materials, the weight of vehicles currently built is similar to those of the 1970s. This is clearly seen in Figure 2. It follows that in 1975-2020 the average fuel economy and horsepower for new light-duty vehicles increase, while weight remains constant. This was due to the fact that the dimensions of the vehicles increased, their range (more powerful engines, larger fuel tanks), and equipment that increased driver comfort (air conditioning, audio players, video, navigation systems). In addition, factors related to safety and environmental requirements (side guards preventing people from getting into the zone between the wheels, anti-skid systems (ABS), catalytic converters) influenced the increase in vehicle weight.

\section{Recycling of selected elements}

Recycling of individual elements of oversized cars is similar to that for passenger cars. After draining all operating fluids, disassembling batteries, easily removable parts (wheels, mirrors, windows), vehicle assemblies and components (engine, drive system) and selected body components (doors, engine covers), the remaining wreck is shredded. In the case of passenger vehicles, it is possible to fragment the whole vehicle, while in the case of trucks such a vehicle must be pre-stratified. Some manufacturers of bulky vehicles (e.g. Scania) issue guidebooks on how to disassemble vehicles and indicate in them, e.g. the type of plastic used to manufacture them, or components made of copper (Scania 2013; Scania 2017).

Materials used in the construction of vehicles that are harder to recycle include, for example, rubbers, such as tires, seals, transmission belts, rubber joints. The largest 


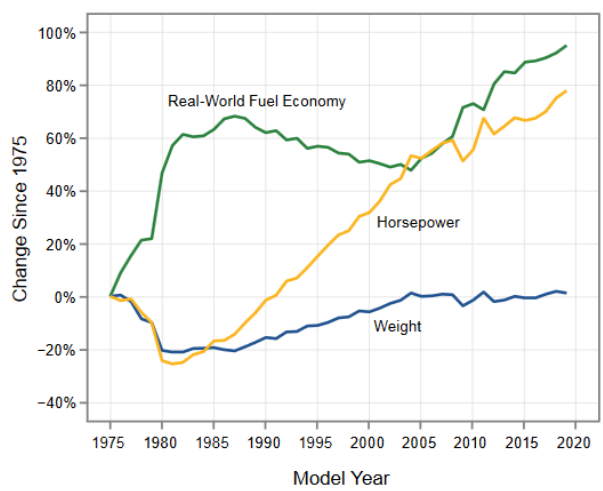

Figure 2. Light-duty vehicle trends - fuel economy, horsepower, and weight in 1975-2020 (EPA 2020)

amount of rubber waste comes from tires whose functional properties, such as resistance to weather conditions and mechanical resistance, make them difficult to handle. Tires are a composite material and consist of many different materials. The proportion of individual materials and the design of the tires and their mass depend on the size and purpose of the tires. Table 1 presents examples of tire composition depending on their type. The average tire weight for passenger cars is from $6.5 \mathrm{~kg}$ to $9 \mathrm{~kg}$, while for longhaul trucks from $55 \mathrm{~kg}$ to $80 \mathrm{~kg}$ (Basel Convention 2002). However, the world's largest tire for very big truck (Belaz 75710 - truck used in open-cast mines.) with a very high payload capacity (450 tonnes) can weigh about $5800 \mathrm{~kg}$ (one tire) and measure over 4. meters in height (Banach 2017).

The difference between truck and passenger tires is not just size. In truck tires the carcass and belts are made of steel but in tires for passenger car of the carcass consist of several layers of textile cord. In truck tires, the rubber on the tread is thicker, so that these tires can be regenerated not used in passenger car tires, namely to regrooving. This operation involves cutting tread pattern deeper than the original. The regrooving is performed with a special cutting tool (gouge) equipped with an electrically heated blade (Prometeon 2020). This operation enables to prolong tire's useful life by about $25 \%$ and is included in product recycling.

Other tire recycling methods are analogous to those for passenger vehicles. These include upcycling, which is considered one of the forms of material recycling. It involves the use of tires for other purposes, where their shape, ability to damp vibrations and noise, or resistance to weather conditions are used. The tires can be used whole, after cutting or pressing. They can be used e.g. as insulation material for building foundations, as road base material, protection of river banks, quays and breakwaters, protective barriers, elements of playgrounds, flowerbeds, etc. (Nèjè 2020; Sybilski 2009). Retreading is also included in the product recycling of tires. It involves removing the old, worn tread to reveal the body (carcass) and applying a new one in the vulcanization process. This operation allows you to reuse $80 \%$ of the original material (Gronowicz and Kubiak 2007; Adamczyk et al. 2019).

Material recycling of tires is associated with their fragmentation, granulate preparation and metal recovery (Tomasiak, Kołosowski, and Malinowski 2018). This is an energy consuming process. Depending on the particle size, material is obtained in the form of pulp, fines, granules, chips or shreds. Abrasive, fine coal and granules are used as a filler for various composites or as building material (in addition to playground surfaces, asphalt, sports equipment, car mats). Shreds and chips are most often filler in elements of building structures - e.g. in the construction of tunnels, underground passages, embankments, as a material for repairing landslides (Oikonomou and Mavridou 2009).

Raw material recycling of tires involves thermal decomposition of pieces or whole tires in a pyrolysis or gasification process. The final product is post-process gases, pyrolysis oil, so-called carbonizate (solid product) and steel from cord and wire. The post-process gas contains light hydrocarbons (mainly methane), hydrogen, hydrogen sulphide and carbon monoxide and can be used as a combustible gas, e.g. for heating 
Table 1. Material compositions of passenger car and truck tires in the European Union (Basel Convention 2002) [in percents]

\begin{tabular}{lcc}
\hline \multicolumn{1}{c}{ Material } & Passenger car & Truck \\
\hline Rubber/elastomers & 47 & 45 \\
\hline Carbon black & 21.5 & 22 \\
\hline Metal & 16.5 & 25 \\
\hline Textile & 5.5 & - \\
\hline Zinc oxide & 1 & 2 \\
\hline Sulphur & 1 & 1 \\
\hline Additives & 7.5 & 5 \\
\hline
\end{tabular}

a reactor. Pyrolytic oil contains a mixture of aliphatic and aromatic hydrocarbons and can be further processed - e.g. by distilling and further processing of chemical compounds, or it can be used as heating oil. In the solid phase, which is in addition to steel and soot, there are zinc oxides and sulphides, silica and the remains of used catalysts (Ryms et al. 2013).

In the case of energy recycling, entire tires, as well as products from material and raw material recycling can be subjected to him. Due to the high sulphur content and the high content of aromatic and polyaromatic hydrocarbons, these materials can be burned in installations adapted to them (Czajczyńska and Krzyżyńska 2016).

Glass waste obtained from car recycling consists mainly of glued, tempered glass and, to a lesser extent, headlight and mirror panes. These elements are usually made of float glass. This glass has an almost perfectly flat surface, there are no distortions or optical defects. Toughened glass is obtained as a result of heating to high temperatures of float glass and its rapid cooling. This results in a change in the glass structure - a regular network of silica microcrystals separated by an amorphous phase is created. Toughened glass breaks into small pieces with blurred edges. Tempered glass is most often used for side and rear windows of vehicles. On the other hand, laminated glass is used as windshields (but also increasingly more often as side windows) and they are the biggest problem when recycling automotive glass. They consist of two layers of glass, joined together by one or several layers of plastic, most often PVB (polyvinyl butyral) film. The process of recycling them is expensive and consists of the following stages: 1 ) storing glass in the open air to reduce the adhesion between the film and the glass, 2) crushing the glass, 3 ) separating the glass from the film and 4) screening. The recovered glass is directed to the smelter, and the main waste from the processing line is contaminated PVB film - it accounts for about $30 \%$ of the charge (Swain et al. 2015). Its recycling is problematic and requires specialized processes due to pollution with fine glass and glass dust, which can constitute about $7 \%$ by weight in plastic waste (Maderski and Gawdzik 2016). Most often, such foil is subject to storage. There are installations around the world enabling good separation of glass from PVB film. One of the methods used is crushing and then grinding such laminated glass to the dust fraction. The polymer is separated from the glass by flotation. The separated materials are drained and dried. However, glass dust management in smelters requires special technologies, which is a problem in Poland.

Disassembly stations for end-of-life vehicles are obliged to remove from it elements and harmful substances, which include operating fluids such as: fuel, brake fluid, washer fluid, coolant fluid, engine oil, transmission oil. These fluids are collected according to the waste code and then transferred to specialized enterprises for their disposal. Brake fluids are used in smaller vehicles, e.g. delivery vans equipped with hydraulic brakes. Air-powered air brakes are used on large trucks and buses. 
Brake and cooling fluids have similar composition (most often based on glycols or polyglycols) and they are subject to similar recycling - after decoupling they are forwarded for regeneration or distillation.

Lubricating oils are especially dangerous for the environment and people, they contain various harmful chemical compounds, including carcinogenic and toxic ones. Due to the fact that hydrocarbons have a significant share in the composition of the oil, such oils can be utilized by combustion or recycled through regeneration / distillation. Such processes are carried out in refineries equipped with appropriate technological lines. An alternative to them is filtration used more and more often, then solvent extraction and adsorption. Those processes are very effective (Osman, Attia and Taman 2018).

Windscreen and headlight washer fluids mainly consist of a solution of ethyl and / or isopropyl alcohol with washing, antifoaming, bactericidal, fragrance and dye additives. These compounds are well soluble in water and therefore pose a great threat to the environment. Their recycling consists mainly in distilling off alcohol and reusing it.

Lead-acid batteries are an environmentally hazardous element of vehicles. They are widely used as starting batteries in both heavy goods vehicles and passenger cars. The battery consists of various material fractions, including: electrolyte, lead paste, metallic fraction and plastic fraction Figure 3 (Zhang 2013). Unfortunately, due to the acid present in the electrolyte and lead (classified as heavy metal), which is part of the paste and the cells in the cells, batteries are classified as hazardous waste. Their recycling is done by specialized companies.

Recycling lead-acid batteries can be accomplished in two ways:

- the first consists in melting the battery together with the fuses (or after removing the acid from it) in a shaft furnace. As a result of this process, antimony lead, silicate slag and lead-iron stone are obtained, which is a raw material for lead smelters;

- the second way is to remove the electrolyte from the batteries and grind them, e.g. in hammer crushers and separate individual fractions: metallic, sulphated lead paste, polypropylene and non-recyclable materials (glass, bakelite, paper, other materials) that are waste. In some cases, entire batteries (including electrolyte) are shredded. Recovered lead and polypropylene are reused in the production of batteries. It is estimated that typical new lead-acid batteries can contain $60-80 \%$ recycled materials (Govindan, Sasikumar and Devika 2010).

Batteries are just one element of the electrical system in vehicles. It also includes lamps, alternator, wire harnesses, connectors, screws, etc. Electrical installations of motor vehicles are increasingly expanded due to the growing number of devices that are powered by them (Kieracińska and Piórkowski 2016, 47). These are not only lighting, starting circuit, fuel pump and radio, but also a computer with data buses, navigation, telephone, as well as comfort and safety elements. It is estimated that a scrap vehicle has an average of about $25 \mathrm{~kg}$ of wiring, of which about $50-55 \%$ is copper and the rest is insulation (Jankowski and Wąsowicz 2018). Depending on the purpose of the cable and its working conditions, its construction can be more complex. It may contain one or several copper wires and, in addition to external insulation, also have internal insulation or a braid (shield). Cable recycling involves the simultaneous crushing and cutting, which allows you to remove insulation and recover copper. Due to the small diameter of the cables used in vehicle wiring harnesses, the most commonly used devices for grinding and removing insulation are devices called granulators. More extensive machines can be used to recycle aluminium cables, cables with a more complex structure (containing steel wire, 


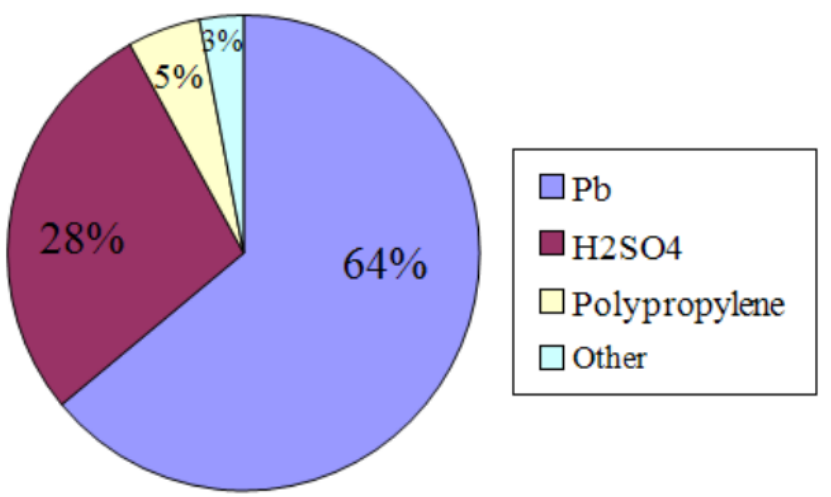

Figure 3. An example of the share of individual fractions in a lead-acid battery (Zhang 2013)

lead tires, Teflon or cotton insulation) and at the same time to process coolers, such as the Entryline line for recycling Stokkermill cables (Figure 4).

Increasingly stringent emission standards on the one hand lead to a reduction in the emission of toxic compounds to the atmosphere, and on the other to an increase in the complexity of exhaust gas treatment systems. This forced the use of almost all groups of vehicles, including trucks, catalytic reactors SCR (Selective Catalytic Reduction) reducing nitrogen oxides. Some trucks also have DOC (Diesel Oxidation Catalyst) catalytic converters installed in the exhaust systems of compression-ignition engines. Combustion of incomplete combustion products such as carbon monoxide and hydrocarbons takes place in these reactors. Particulate organic fractions are also partially fired up. In order to reduce the amount of particulate matter emitted to the atmosphere, DPF (Diesel Particulate Filter) is installed. To improve the efficiency of exhaust gas purification, catalytic converters and filters are combined into one system. An example is the CRT (Continuous Regeneration Trap) system used in trucks. It combines the operation of an oxidizing catalytic converter and a particulate filter. The catalytic reactor consists of a honeycomb ceramic or metal monolith. A very thin active layer composed of precious metals belonging to platinum (platinum, palladium and rhodium or ruthenium) is applied to the monolith. The content of platinum group metals in the automotive catalytic converters can be up to $2000 \mathrm{~g}$ per ton and it is much higher than in fossil ores - on average below $10 \mathrm{~g}$ per ton (Hagelüken 2012). It causes that the recycling of catalytic converters is very attractive from an economic point of view.

Catalyst reactors after disassembly are stripped of their housing and sorted according to the content of platinum. The ceramic inserts are ground in ball mills and a thorough analysis of the samples of ground catalysts is carried out. Then the ground and examined material is sent to metallurgical and metallurgical concerns, where the precious metal recovery process is carried out. In Poland, reprocessing of spent catalytic converters is practically not carried out. The reactors are bought by enterprises and then sent to countries where there are companies specializing in the recovery of platinum metals from catalysts, e.g. to Germany or Great Britain (Trębacz and Michno 2017).

Plastics and polymer composites are commonly used in the automotive industry for the production of over a thousand different types of vehicle construction elements. They have found application in virtually most of the vehicle's external and internal components. Polymer materials are produced, among others seats, switchboards, upholstery, bumpers, mirror housings, body 


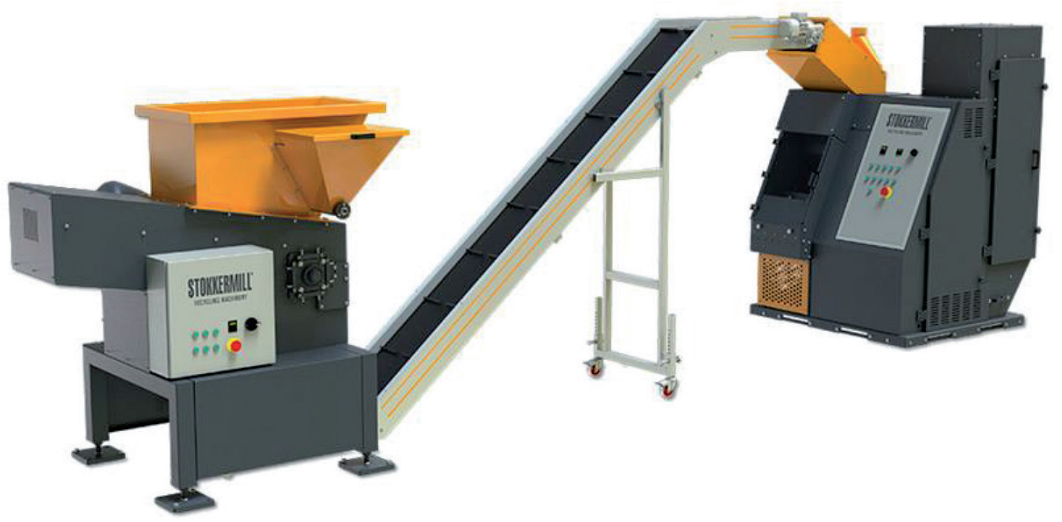

Figure 4. Stokkermill Entryline line for processing copper and aluminium cables and coolers (Stokkermill 2020)

components (Friedrich and Almajid 2013). In the construction of trucks, polymers belonging to two groups are used: thermoplastics (meltable) and thermosets (non-meltable), among which the dominant materials are: polypropylene, polyethylene, polyurethanes, polyamides, polyvinyl chloride, acrylonitrile-butadiene-styrene and polycarbonates. Figure 5 shows examples of the use of these groups of plastics in the construction of a Scania truck.

Plastics dismantled from vehicles and sorted are subject to the same recycling methods as plastics from other industries. They can be subjected to depolymerization, material, raw material, energy recycling or storage.

On average, automotive vehicles contain about $70 \%$ of metals and their alloys. These materials are easily subject to material recovery in traditional metallurgical processes and retain all their natural properties when reused. The dominant technology for preparing car scrap for recycling is shredding combined with magnetic separation (ferrous metals), air separation (light fractions), using eddy currents (metals-non-metals). In the case of separating steel from unsorted waste or from elements containing other materials (e.g. rubber, plastics), the waste incineration method is used. Then the metal is recovered from the ash by magnetic methods. This method is not applicable to tin and
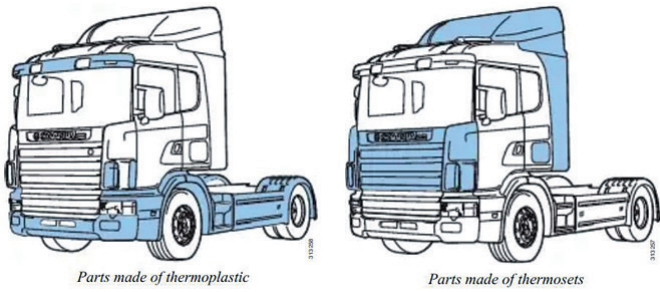

Figure 5. Examples of the use of plastics in the construction of a Scania truck (Scania 2012)

aluminium. After removing ferromagnetic fragments with magnets, non-magnetic metals are separated using density differences (air separation) and eddy currents (Ligus 2012).

In the case of small companies dealing with the dismantling of end-of-life vehicles, it is expedient to pre-select groups of materials. This selection can be carried out using small grinding equipment (ball mills), followed by magnetic and eddy-current separators. As a result of these activities, it is possible to obtain valuable commercial raw materials such as zurik and zorba. Zorba it is a shredded nonferrous scrap that is predominantly aluminium and zurik it is a sensor-sorted shredded nonferrous scrap that is predominantly stainless steel. These raw materials can be resold to large-scale material recycling companies, which further segregate these materials and transfer them to steel mills. 


\section{Conclusion}

The number of used heavy goods vehicles is increasing every year and generates an increasing number of end-of-life vehicles. Withdrawn vehicles are treated as waste. While in the case of passenger vehicles there is an obligation to recycle them, there is no such obligation for large-size vehicles.

Large-size car designs are different from passenger cars, but the construction materials used are similar, only the share of individual types of materials may be different. The automotive industry uses various materials, e.g. different types of steel, aluminium, copper, magnesium, glass, plastics, composites and carbon fibres. The choice of material is determined by many factors, including thermal, mechanical and chemical resistance, durability, the ability to absorb energy, ease of production, and costs. In the automotive industry, there is a growing interest in the use of lightweight materials with good mechanical properties, which results from limiting the weight of vehicles and translates into less fuel consumption and lower emissions. Hence, the increased share of composite materials, aluminium, magnesium and high-strength steel in the construction of vehicles. Increasing the strength of truck components has resulted in cost-effective recovery, which is carried out by some concerns. This recovery and sorting of materials are to be facilitated by guides issued by vehicle manufacturers on how to carry out disassembly and the construction materials used.

For end-of-life vehicles with large dimensions, analogous recycling methods are used as for passenger vehicles, i.e. product, material and energy recycling. Some differences may result from the size of the elements themselves. For example, in the case of oversized cars, it is not possible to enter the entire vehicle wreck into the shredder, which can be implemented in the case of passenger cars. Another example is the regeneration of truck tires by regrooving, which is not used in passenger car tires due to the low thickness of the rubber on the tread.
Recycling technologies for many vehicle components, due to their material composition, are already well known and implemented. This applies to some polymeric materials or elements made of steel. However, there are still many challenges ahead. Some multi-component materials (composites) or some plastics pose a problem. Burning them is an irreversible waste of raw materials. For some recycling technologies there is a lack of adequate infrastructure in Poland. An example is the recycling of laminated car windows by crushing and then grinding to the dust fraction. This method allows very good separation of PVB film from glass, however, the management of glass dust in smelters requires special technologies, which is a problem in Poland. Another example is the recycling of catalytic converters. The monolith of the reactor is covered with a thin active layer, composed of precious metals belonging to the platinum group (platinum, palladium and rhodium or ruthenium). The recovery of these metals is the main premise for their recycling, however, it is practically not implemented in Poland. The reactors are only bought by enterprises and then sent to countries where there are companies specializing in the recovery of platinum metals.

\section{Bibliography}

Act 2005 - Act of 20 January 2005 on the recycling of end-of life vehicles. (U. 2005, No. 25, item 202)

(Dz.U. Journal of Laws of the Republic of Poland).

Adamczyk, Janusz, Mirosław Gulba, Michał Sąsiadek, Wojciech Babirecki, Małgorzata Śliwa, and Michał Ociepa. 2019. „Rubber waste management.” Scientific Papers of The Silesian University of Technology. Organisation and Management Series 137: 7-21. http://dx.doi.org/10.29119/1641-3466.2019.137.1.

Banach, Michał. 2017. „10 największych ciężarówek na świecie." Smart Age, August 26, 2017. https://www.smartage.pl/10-najwiekszych -ciezarowek-na-swiecie/.

Basel Convention. 2002. Technical guidelines on the identification and management of used tyres. Basel: UNEP. 
Czajczyńska, Dina, and Renata Krzyżyńska. 2016. "Piroliza jako metoda termicznej utylizacji zużytych opon." W Interdyscyplinarne Zagadnienia w Inżynierii i Ochronie Środowiska. vol. 8, red. Bartosz Kaźmierczak, Andrzej Kotowski, i Katarzyna Piekarska, 54-66. Wrocław: Oficyna Wydawnicza Politechniki Wrocławskiej.

Directive 2000/53/EC - Directive 2000/53/EC of the European Parliament and of the Council of 18 September 2000 on end-of life vehicles - Commission Statements.

Directive 2007/46/EC - Directive 2007/46/EC of the European Parliament and of the Council of 5 September 2007 establishing a framework for the approval of motor vehicles and their trailers, and of systems, components and separate technical units intended for such vehicles (Framework Directive).

EPA. 2020. "The 2019 EPA Automotive Trends Report. Greenhouse Gas Emissions, Fuel Economy, and Technology since 1975." EPA-420-S-20-001, March 2020. https://nepis.epa.gov/Exe/ZyPDF. cgi?Dockey=P100YVK3.pdf.

Fentahun, Mekonnen Asmare, and Mahmut Ahsen Savaş. 2018. "Materials Used in Automotive Manufacture and Material Selection Using Ashby Charts." International Journal of Materials Engineering 8(3): 40-54. https://doi:10.5923/j. ijme.20180803.02.

Friedrich, Klaus, and Abdulhakim A. Almajid. 2013. "Manufacturing Aspects of Advanced Polymer Composites for Automotive Applications." Applied Composite Materials 20:107-128. https://doi. org/10.1007/s10443-012-9258-7.

Govindan, Kannan, P. Sasikumar, and Kannan Devika. 2010. "A genetic algorithm approach for solving a closed loop supply chain model: A case of battery recycling." Applied Mathematical Modelling 34(3): 655-670. https://doi.org/10.1016/j. apm.2009.06.021.

Gronowicz, Jan Kubiak, i Teresa Kubiak. 2007. "Recykling zużytych opon samochodowych.” Problemy Eksploatacji 2: 5-18.

Hagelüken, Christian. 2012. "Recycling the Platinum Group Metals: A European Perspective.” Platinum Metals Review 56(1): 29-35. http://dx.doi. org/10.1595/147106712X611733.

Jankowski, Krzysztof, i Alicja Wąsowicz. 2018. "Logistyka w procesie recyklingu okablowania samochodowych instalacji elektrycznych."
Autobusy 19(4): 43-47. https://doi.org/10.24136/ atest.2018.019.

Kieracińska, Anna, and Piotr Piórkowski. 2016.

"Analysis of the reasonableness of using electric drives in motor vehicles." The Archives of $\mathrm{Au}$ tomotive Engineering 74(4): 47-58. https://doi. org/10.14669/AM.VOL74.ART4.

Ligus, Grzegorz. 2012. "Separacja niemetalicznych frakcji zmieszanych odpadów komunalnych." Prace Instytutu Ceramiki i Materiałów Budowlanych 5(10): 57-67.

Maderski, Tadeusz, i Alicja Gawdzik. 2016. "Recykling odpadów z szyb samochodowych i szkła budowalnego z folią PVB." Proceedings of ECOpole 10(2): 721-731. https://doi:10.2429/ proc.2016.10(1)079.

Mayyas, Ahmad T., Abdel R. Mayyas, and Mohammed Omar. 2016. "11 - Sustainable lightweight vehicle design: A case study in eco-material selection for body-in-white." In Lightweight Composite Structures in Transport. Design, Manufacturing, Analysis and Performance, edited by James Njuguna, 267-302. Oxford: Woodhead Publishing. https:// doi.org/10.1016/B978-1-78242-325-6.00011-6.

Miller, Lindsay, Katie Soulliere, Susan Sawyer-Beaulieu, Simon Tseng, and Edwin Tam. 2014. "Challenges and Alternatives to Plastics Recycling in the Automotive Sector." Materials 7(8):5883-5902. https://doi:10.3390/ma7085883.

Oikonomou, Nikolaos, and Sofia Mavridou. 2009. "The use of waste tyre rubber in civil engineering works." In Sustainability of Construction Materials, edited by Jamal Khatib, 213-238. Woodhead Publishing. https://doi:10.1533/9781845695842.213.

Osman, Doaa I., Sayed K. Attia, and Afaf R. Taman. 2018. "Recycling of used engine oil by different solvent." Egyptian Journal of Petroleum 27(2): 221-225. https://doi.org/10.1016/j.ejpe.2017.05.010. Prometeon. 2020. "Regrooving info." Accessed May 20, 2020. https://www.prometeon.com/ tyres/en-ww/truck_bus/find-your-tyres/ truck-knowledge/regrooving-info.

Ryms, Michał, Katarzyna Januszewicz, Witold M. Lewandowski, and Ewa Klugmann-Radziemska. 2013. "Pyrolysis Process of Whole Waste Tires as a Biomass Energy Recycling." Ecological Chemistry and Engineering $S$ 20(1): 93-107. https://doi. org/10.2478/eces-2013-0007. 
Scania. 2012. "Identification of Materials. Plastics." Scania CV AB 2012, Sweden. http://bit.ly/ scania-2012.

Scania. 2013. "Dismantling information. Scania Touring. Scania - Higer A80, A30. Work description." 00:45-51. Scania CV AB 2013, no. 3, en-GB. http://bit.ly/scania_2013.

Scania. 2017. "Dismantling information. P, G, R and S series." Scania CV AB, December 2017, en-GB. https://til.scania.com/groups/dis/documents/dis/ xzaw/mdax/ edisp/dis_0000113_01.pdf.

Stokkermill. 2020. "Entryline - linia do recyklingu kabli." Accessed May 25, 2020. https:// www.stokkermill.com/instalacje-recykling/ entryline-kable-recykling.

Stopka, Ondrej, Branislav Šarkan, Jan Vrabel, and Jacek Caban. 2018. "Investigation of fuel consumption of a passenger car depending on aerodynamic resistance and related aspects: a case study." The Archives of Automotive Engineering 81(3):129-136. https://doi.org/10.14669/AM.VOL81. ART9.

Swain, Basudev, Jae Ryang Park, Jae Ryang Park, Kyung-Soo Park, Myung Hwan Hong, and Chan Gi Lee. 2015. "Recycling of waste automotive laminated glass and valorization of polyvinyl butyral through mechanochemical separation." Environmental Research 142: 615-623. https://doi. org/10.1016/j.envres.2015.08.017.

Sybilski, Dariusz. 2009. "Zastosowanie odpadów gumowych w budownictwie drogowym." Przeglad Budowlany no. 5: 37-44.

Synák, František, Ján Gaňa, Vladimír Rievaj, and Lenka Mokričková. 2019. "Ways of reducing carbon dioxide from road transport." The Archives of Automotive Engineering 86(4): 41-54. https://doi. org/10.14669/AM.VOL86.ART3.

Todor, Mihai-Paul, and Imre Kiss. 2016. "Systematic approach on materials selection in the automotive industry for making vehicles lighter, safer and more fuel-efficient." Applied Engineering Letters 1(4): 91-97.

Tomasiak, Jacek, Mariusz Kołosowski, i Przemysław Malinowski. 2018. "Innowacyjny sposób wykorzystania zużytych opon samochodowych w procesie wypalania klinkieru cementowego." W Innowacje w zarzadzaniu i inżynierii produkcji, vol. 1, ed. Ryszard Knosal, 346-355. Opole: Oficyna Wydawnicza Polskiego Towarzystwa Zarządzania Produkcją. Dostęp 24.06.2020. http://www.ptzp. org.pl/files/konferencje/kzz/artyk_pdf_2018/ T1/2018_t1_346.pdf.

Trębacz, Hubert, and Piotr Michno. 2017. "The Evaluation of Platinum Group Metals (PGMs) and Their Recovery From Car Catalytic Converters." Structure and Environment 9(2): 133-147.

Wartgow, Gregg. 2020. The role of composites in heavy duty trucks. Accessed 26.06.2020. https:// www.vehicleservicepros.com/vehicles/on-thevehicle/cab-body/article/21125653/the-role-ofcomposite-materials-in-heavy-duty-trucks.

Wilhelm, M. 1993. "Materials used in automobile manufacture - current state and perspectives." Journal de Physique IV Colloque 3(C7): 31-40. http://dx.doi.org/10.1051/jp4:1993703.

Zhang, Qianyu. 2013. "The Current Status on the Recycling of Lead-acid Batteries in China." International Journal of Electrochemical Science 8: 6457-6466. 